\title{
Development of Learning Media for Early Childhood Education Teacher in Stimulating the Polite Behavior Through Macro Role Play in Gorontalo City
}

\author{
Ruslin Badu \\ Faculty of Education \\ State University of Gorontalo \\ Gorontalo, Indonesia \\ ruslinbadu@gmail.com
}

\begin{abstract}
This research aims at developing the learning media for early childhood education teacher, thus it can help to stimulate, to develop, and to evaluate the polite attitude in early childhood through macro role-play. The specific objective of this research is the availability of computer-based learning media in the form of VCD that consists of the main menu on the procedure of the role-play, guideline function, objectives, materials, and evaluation. These are all expected to ease teacher in implementing the learning especially in stimulating the polite attitude in early childhood. This is based on the awareness of the importance of using the appropriate media in order to help the teacher improve both the learning process and the learning outcome of the early childhood. This research uses research and development method $(R \& D)$
\end{abstract}

Keywords-Development, learning media, polite attitude, macro role-play

\section{INTRODUCTION}

The success of Early Childhood Education (PAUD) largely relies on many influencing components, one of them is the teacher, in which, and teacher's competencies strongly determined his /her professionalism in teaching the early childhood. Within the frame of teacher's development, the teachers are always expected to improve their competencies. Teacher has to learn, either through formal education or through independent learning. In order to develop the independent learning, a practical and easy to understand by the children learning media is needed.

As an effort to facilitate the availability of that kind of learning media, learning media development is needed. The developed media has to be suitable with the child's development; one of the programs is through stimulating the early childhood's polite behavior. In the quest of finding out the extent of polite attitude mastered by the early childhood a development through using the macro role-play learning media is needed. This is because the children are often fond of macro role-play. Through macro role-play, the children play the role of the figures surrounding them such as how to act politely toward each other; the children dramatize the behavior of interaction with others in their environment.

\section{THEORETICAL BACKGROUND}

Politeness (Dessy, Rabiah, 2009: 23) is the attitude to act politely, respecting others, and not talking in appropriate language and not behaving arbitrarily. In early childhood, the criteria of politeness are defined within the curriculum written under the development of the Religious and Moral Values (Permen 58. 2009: 11) with the criteria of achievement as follow: (1) giving and returning greet, (2) greeting friends and others politely, (3) asking for help politely, (5) thanking others properly when given something and gained something.

Those polite attitudes are gained by the early childhood through continuous learning process through observation, imitating and appreciation of interaction with the environment, whether in school, peers, or community. Several causes of the lack of politeness in early childhood probably is due to the lack of good example from school, in this term, the teachers of PAUD in implementing the values of politeness and good behaviors. On the other hand, teachers of PAUD become the direct role model for the children on how to behave properly and to act politely according to the norms of the daily life. In addition to this lack of good role model, the cause of instability of the polite behavior on children is the lack of attention and positive responds from the family, school, and community, thus it brings a fatal consequence on the early childhood.

To develop the polite behavior of the early childhood, teachers are expected to optimize it through using the learning media. Therefore, an appropriate learning media adjusted to the level of early childhood development are needed by implementing the method of macro role-play to overcome the problem of lack of politeness in the early childhood.

The research chosen to develop the learning media based on VCD to stimulate the polite behavior of the early childhood, by using the clear and systematic steps to make the process easy for the researcher. The development of VCD based learning media to stimulate the polite behaviors is done to find out the extent of the quality and effectiveness of the learning media. 


\section{METHOD}

This research uses research and development method to produce validated learning media for the teachers of PAUD in stimulating the polite behavior in early childhood through macro role-play. Further, the qualitative and quantitative analysis was conducted. The procedure made in this research is based on the approach of research and development (R \& D).

The final objective of research and development is to produce the product that can help the PAUD teachers in stimulating the polite behavior of the early childhood through macro role-play, and further conduct the experimental test to gain a final learning media.

Steps of the material test implementation

\section{A. Trial Test of the Developed Material}

Try out of the material for macro role-play aims at collecting the data on the response of the polite attitude of the early childhood in the implementation of macro role-paly. The data obtained then used to analyze and used to improve or perfecting the developed materials.

\section{1) Subject of the try out}

The subject of the trial test is the 25 randomly chosen early childhood from 5 Kindergartens/PAUDs to be the subject of the material trial test for their polite behavior.

\section{2) Types of data}

The data in this trial stage of the developed learning media is the quantitative method of the questionnaire score on the polite behavior of the early childhood on their participation in macro role-play

\section{3) Data collection method}

The data collected through observation and questionnaire. Observation is providing the observation sheet used to note the importance events and the children's responds during the macro role-play activities during the trial stage. Meanwhile the questionnaire is used to measure the children's ability in observing the macro role-play material.

\section{4) Data Analysis Technique}

The data from the trial stage consists of the ability to act politely in early childhood, analyzed quantitatively on the differentiation test with the t-test for paired samples to find out whether the significant differentiation on the early observation and final observation exist.

\section{5) Trial stage of the Learning Media Product}

The trial of the learning media product aims at collecting the data on the quality of the developed learning media, whether from its function, the content, and the appearance. The data obtained from this stage then analyzed and used to improve and perfect the developed product. Through this stage of trial, it is expected that the quality of the produced learning media can be well developed.

6) The design of the trial

The implementation of the trial stage is conducted through the following stage:

\section{a) Validation by the media experts}

Before the learning media is tried to the teachers of PAUD, the media is validated by one media expert. The media expert is chosen from the department of education technology, a postgraduate lecturer at State university of Gorontalo. The assistance of the expert, the assessment, and the comments and recommendation is strongly needed in order for the developed product to meet the objective of finding out the politeness attitude of the early childhood. The media expert gave assessment toward the product from its appearance then the try out was conducted.

\section{b) The field trial}

The field trial conducted to determine whether the developed product is suitable, from is material aspect, its appearance, and its function thus it is appropriate to be used. The procedures for this field trial are as follow:

a) Randomly choosing 10 teachers of PAUD

b) Describe to the teachers of PAUD the goals and objectives of the field trial

c) Ask the teachers of PAUD to learn the learning media that has been made available

d) Record all the responds of the teachers of PAUD during the usage of the learning media

e) Ask the teachers of PAUD to fill the questionnaire to find out their responds on the developed media

f) Analyze the data obtained (the score on the responds toward the material, the appearance, and the function of the developed product)

\section{7) The subject of the trial}

The subjects of the trial are 10 PAUD teachers. The subjects are those PAUD teachers participating in the training conducted by the HIMPAUDI of Gorontalo Province and the HIMPAUDI of Gorontalo City.

\section{8) Types of Data}

The types of data in this stage are the qualitative data and the quantitative data. The qualitative data are the comments and the recommendation for refinement from the media expert, the expert of learning materials, and the PAUD teachers as the subject of the material trial. The quantitative data is the score on the responds on the developed media.

\section{9) The data collection method}

The data collection methods used in this research are observation and questionnaire. Observation is used to record the important events and children's responds during the trial. The questionnaire is used to assess the competencies of the early childhood in participating on the macro role-paly and in behaving politely and on the quality of the developed product from its material aspect, the appearance aspect, and its functions aspect.

\section{0) Data analysis technique}

Within the stage of media development, the data was analyzed using the descriptive qualitative analysis on the recommendation for the refinement from the validator, expert teachers, and teachers of PAUD, and quantitative analysis to assess the level of validity of the learning media using the formula of the data assessment that has been modified to 
become quantitative data and the average data as seen in the following Table 1.

TABLE I.

\begin{tabular}{lll}
\hline No & Score Range (i) & Category \\
\hline 1. & $X>X i+1.80 \mathrm{Sbi}$ & Strongly Valid \\
2. & $X i+0.6 \mathrm{SBi}<X \leq \mathrm{Mi}+0.060 \mathrm{SBi}$ & Valid \\
3. & $X i-0.6 \mathrm{SBi}<X \leq \mathrm{Mi}+0.060 \mathrm{SBi}$ & Moderately Valid \\
4. & $X i-1.80 \mathrm{SBi}<X \leq \mathrm{Mi}+0.060 \mathrm{SBi}$ & Less Valid \\
\hline
\end{tabular}

\section{DISCUSSION}

During the early observation stage, the objective of this stage was to analyze the characteristics of the early childhood, and the material analysis that would be developed. The next stage is the production of the learning media on the polite behavior, in the stage of pictures taking, and the initial design of the learning media, learning media that has been revised by the validators of the materials to find out the things and aspects that need to be improved within the learning media. The validators consist of the material expert and the media expert. Before the media is trialed, the developed product is trialed on to the small group of 10 early childhoods that were randomly chosen from five PAUD that becomes the target of the research, the result from this trial stage then analyzed.

The revision based on this trial then endures the field trial in PAUD K. H. Dewantoro of Kota Selatan, City of Gorontalo.

The result of this try out reveal the highest score on the appropriateness of the learning media, it is appropriate with the standard that is the appropriate and very appropriate standard. Overall the learning media is appropriate. The developed learning material assessment has reached $90 \%$, which means that the VCD based learning media has a very appropriate qualification to be used because it has the range of score from $81 \%$ to $100 \%$. Further, the field trial was conducted to the 25 early childhoods. From this field trial, the overall assessment and responds through questionnaire during the field trial toward the VCD based learning media obtained $98 \%$ and qualified as very appropriate.

From the above explanation, it is clear that the path of the development of the learning media in several stage experienced adjustment based on the situation on the field. Those adjustments produced the new modification path from the researcher that can be used as reference in developing learning media for further researchers.

\section{CONCLUSION}

1. That learning media was able to stimulate the polite behavior in early childhoods as expected especially related to the mastery, characteristics of the early childhood, and the designing of the learning media, and the implementation of learning media evaluation.

2. The development of learning media in stimulating the polite behavior through macro role-play improving the PAUD teachers' competencies in implementing learning in their school environment has improved.

3. The implementation of the developed learning media in stimulating the polite behavior was proven to be effective in stimulating the polite behavior of the early childhoods.

4. The result of developed learning media implementation is quite effective. It significantly influenced the improvement of the polite behavior of the early childhoods.

\section{RECOMMENDATION}

In specific, this developed learning media is recommended to the policy makers that were strongly related to the implementation of the learning media namely:

a. The head of the Education Department of the Gorontalo Province, the Head of the Department in the city and districts level, to recommend the implementation of this VCD based learning media to stimulate the polite behavior in the early childhoods.

b. There is a need of guidance involvement of the PAUD teachers in every empowerment activity through seminars, discussion that has to be programmed by the education departments either in the provincial level Orin the districts and city level. Thus the PAUD teachers can improve their knowledge in implementing a more qualified and optimal learning in the school level, thus it would bring impact on the quality of the early childhoods.

c. The teachers of PAUD should always try to improve their competencies in implementing their responsibility as teachers of PAUD, thus they can perform their duty in school without any obstacles, and they would be able to produce qualified early childhoods.

\section{REFERENCE}

[1] Alhafizh. 2009. Media pembelajaran Bermain Peran (RoxPlaying).Alhafizh84.wordpress.com/2009/12/21. Diakses 21 Desember 2009.

[2] Arsyad, A. (2006) Media Pembelajaran. Jakarta: Raja Grafindo Persada

[3] Arya, Utama. 2009. Ilmu Psikologi. Wordpress.com/2009/12/15. Diakses Tanggal 15Desember 2009

[4] BPPLSP. 2007. Media pembelajaran Taman Penitipan Anak

[5] Dahli, Ahmad. 2009. Media pembelajaran Bermain Peran dalam PembelajaranPartisipatif. Dahli ahmad.blogspot.com/2009/03. Diakses tanggal 29 Maret2009.

[6] Dessy, Rabiah. 2009. Hakekat, Perilaku, Sopan Santun. http://www.41cIndonesia.org/?page-id\%301315. Diakses tanggal 2 Juli 2009

[7] Didik (2008). Multimedia Pembelajaran Interaktif. Diakses tanggal 27 Desember dari http://didikwirasamodra. Wordpress.com/ 2008/09/05/multimedia

[8] Felix, Antonius. 2008. Pengertian Perilaku. Antoniusfelixshared.blogspot.com. Diakses tanggal 29 Oktober 2008.

[9] Megawangi, Ratna. 2004. Pendidikan Karakter, Solusi yang tepat untuk MembangunBangsa. Jakarta: Migas dan Star Energi, Indonesia Hertage fondation.

[10] Mubayidh, Makmum. 2007. Kecerdasan dan Kesehatan Emosional Anak (referensi penting bagi guru PAUD dan Guru PAUD). Jakarta: Pustaka Al-Kautsar.

[11] Notoatmojo. 2008. Definisi Persepsi \& Perilaku.www.infoskripsi.com/fice-resource. Diakses tanggal 2 September 2008.

[12] Satibi, H. Otib. 2008. Metode Pengembagan Moral dan Nilai-nilai Agama. Jakarta: Universitas Terbuka. 

$\begin{array}{lccc}\text { [13] } \begin{array}{l}\text { Soeharto. } \\ \text { psikomalangraya.blogspot.com/2010/05/01. diakses tanggal }\end{array} \text { Pei } 2010 . & \text { Perilaku. }\end{array}$

[14] Sudjana, N. \& Rivai, A. (2005). Teknologi Pengajaran, Bandung: Sinar Baru Algesindo.

[15] Syamsi. 2010. Pengertian Bermain Peran. uhaysyamsiblogsaya. blogspot. com/2010/11/24. Diakses tanggal 24 November 2010.

[16] Yeni N. Dewi. 2010. Strategi Pembelajaran dengan Bermain Peran. Edukasi kompasiana.com/2010/10/20. Diakses tanggal 20 Oktober 2010. 